\title{
Expression of chemokine receptors CXCR1 and CXCR2 during cardiopulmonary bypass
}

\author{
Ahmad D. Chishti, FRCA ${ }^{a}$ \\ John H. Dark, FRCS ${ }^{a}$ \\ Patrick Kesteven, $\mathrm{PhD}^{\mathrm{b}}$ \\ Hazel Powell, FFA RCS ${ }^{b}$ \\ Christopher Snowden, FRCA ${ }^{a}$ \\ Brian K. Shenton, $\mathrm{PhD}^{\mathrm{a}}$ \\ John A. Kirby, PhDa \\ Simon V. Baudouin, MRCPa
}

From the School of Surgical and Reproductive Sciences, Medical School, ${ }^{\mathrm{a}}$ University of Newcastle upon Tyne, Framlington Place, and the Freeman Hospital, ${ }^{\mathrm{b}}$ University of Newcastle upon Tyne, High Heaton, Newcastle upon Tyne, United Kingdom.

Supported by the British Journal of Anaesthesia.

Received for publication Oct 24, 2000; revisions requested March 22, 2001; revisions received April 18, 2001; accepted for publication April 19, 2001

Address for reprints: A. D. Chishti, FRCA, Department of Anaesthesia and Intensive Care, Royal Victoria Infirmary, Newcastle upon Tyne, NE1 4LP, United Kingdom (Email: Ahmad.Chishti@ncl.ac.uk).

J Thorac Cardiovasc Surg 2001;122:1162-6

Copyright (C) 2001 by The American Association for Thoracic Surgery

$0022-5223 / 2001 \$ 35.00+0 \quad \mathbf{1 2 / 1 / 1 1 6 5 5 9}$

doi:10.1067/mtc.2001.116559
Objective: This study investigated the effects of cardiopulmonary bypass on neutrophil expression of chemokine receptors, CXCR1 and CXCR2, and the $\beta_{2}$ integrin CD11b.

Methods: Ten patients undergoing coronary artery grafting with cardiopulmonary bypass were studied. Blood samples were collected preoperatively, before bypass, at termination of bypass, and 12 to 18 hours postoperatively. In vitro studies were performed on control subjects to determine changes in the surface expression of CXCR1, CXCR2, and CD11b on stimulation with interleukin 8. Receptor expression was measured by flow cytometry. Plasma levels of interleukin 8 from the patients were determined by enzyme-linked immunoassay.

Results: After bypass, CXCR2 expression fell by 66\% $(P<.0001)$ and remained low postoperatively $(P<.0001)$. CXCR1 expression persisted at preoperative levels. CD11b expression increased significantly after bypass $(P<.0001)$, returning to prebypass levels postoperatively. In vitro studies showed a dose-related fall of both CXCR1 $(P<.0001)$ and CXCR2 expression $(P<.0001)$ and a significant rise in CD11b expression $(P<.0001)$. Plasma interleukin 8 increased significantly after bypass $(P<.0001)$, remaining elevated 12 to 18 hours postoperatively $(P=.02)$. Correlations between interleukin 8 levels and CXCR2 expression $(P<.0001)$ and $\mathrm{CD} 11 \mathrm{~b}$ expression $(P<.03)$ were demonstrated.

Conclusions: CXCR2 expression is significantly down-regulated after bypass; in contrast, CXCR1 expression remains unchanged. In addition, whereas interleukin 8 is an important determinant of both CXCR 1 and CXCR2 expression in vitro, it only correlates with CXCR2 and CD11b expression in vivo. This has implications in the search for antagonists against CXC chemokines and their receptors

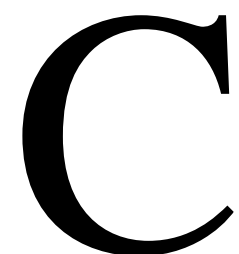

ardiopulmonary bypass (CPB) contributes to the morbidity and mortality of cardiac surgery by its ability to initiate a systemic inflammatory response. ${ }^{1}$ Understanding the molecular mechanisms responsible for neutrophil leukocyte recruitment after CPB is central in developing strategies to limit the adverse effects of acute inflammation. Chemokines play a central role in polymorphonuclear leukocyte recruitment and activation. Interleukin 8 (IL-8) is a prototypical member of the CXC group $^{2}$ and has a key role in neutrophil migration and activation in animal models of acute inflammatory disease ${ }^{3}$ and increases after $\mathrm{CPB}^{4}$ and reperfusion injuries. ${ }^{3}$

In vitro studies using IL-8 receptor antagonists have demonstrated the importance of IL-8-induced signal transduction in neutrophil migration, activation, and 

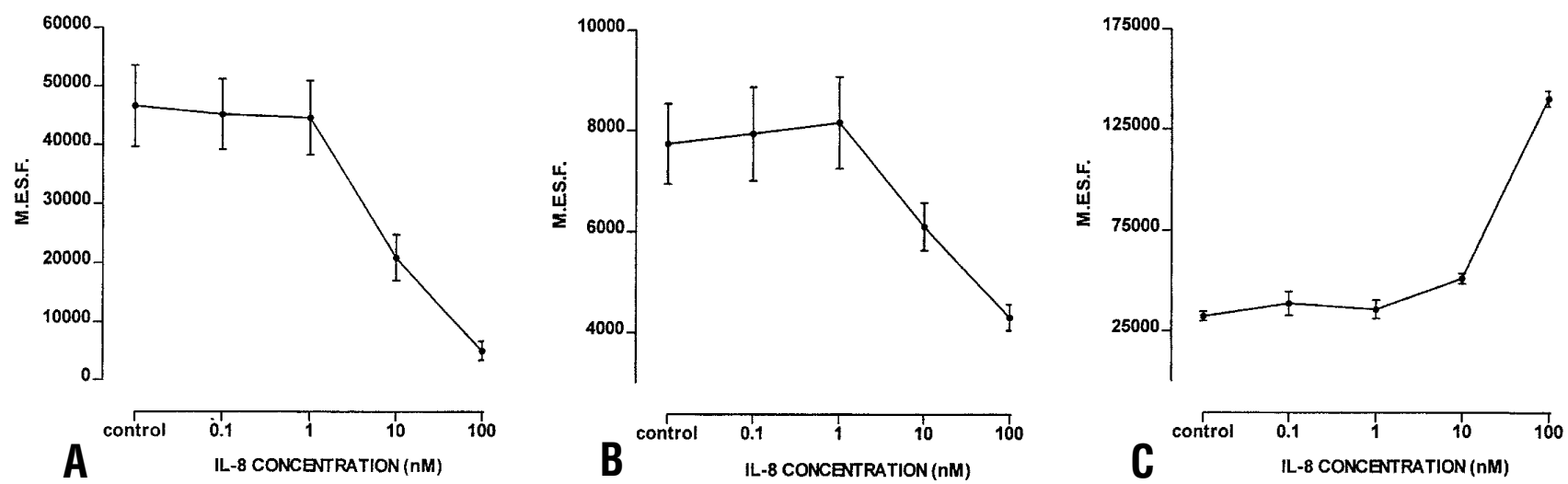

Figure 1. In vitro effect of IL-8 stimulation on neutrophil CXC receptor and CD11b integrin expression. Whole blood preparations were treated for 30 minutes at $37^{\circ} \mathrm{C}$ with varying concentrations of IL-8. Results are the mean of 4 separate experiments \pm SEM and are expressed as molecules of equivalent soluble fluorochromes (M.E.S.F.). A, CXCR1. B, CXCR2. C, CD11b. A significant reduction in both CXCR1 and CXCR2 expression occurred on exposure of neutrophils to IL-8; in contrast, CD11b expression increased significantly.

degranulation. ${ }^{5}$ The plasma concentration of IL-8 receptor expression during CPB is therefore likely to be an important determinant of neutrophil-induced injury after CPB. We therefore studied the effect of CPB on the surface expression of the two principal CXC receptors (CXCR1 and CXCR2) on polymorphonuclear leukocytes. In addition, we examined the relationship between IL-8 receptor expression and circulating IL-8 levels in the peribypass period.

\section{Patients and Methods}

\section{Patients}

Ten patients undergoing elective coronary artery bypass grafting with CPB were included in the study. The Newcastle and North Tyneside Joint Ethics Committee approved the study, and written informed consent was obtained from participating patients. After surgery, a multiple organ dysfunction score and a Murray lung injury score were determined for each patient. 6,7

\section{Anesthesia and CPB}

Patients underwent standard hypothermic CPB with an extracorporeal membrane oxygenator (Cobe-Duo; Cobe, Denver, Colo). After the operation, patients were transferred to the cardiac intensive care unit. Ventilation and sedation (propofol and morphine sulphate mixture) were continued until weaning and extubation. Complications after the operation were treated appropriately according to unit protocols.

\section{Cytokine and Receptor Measurements}

Venous blood samples were collected at 4 time points: 24 hours preoperatively, after induction of anesthesia but before sternotomy, after cessation of CPB (within 30 minutes), and 12 to 18 hours postoperatively in the intensive care unit. All samples were obtained from internal jugular central venous lines. The first $5 \mathrm{~mL}$ of blood was discarded, and samples were immediately placed on ice before transfer and processed within 30 minutes of collection.

\section{Antibodies}

The monoclonal antibodies (MoAbs) used were of the purified immunoglobulin $\mathrm{G}$ type, and experiments included irrelevant isotype-matched MoAb as negative controls. MoAbs directly conjugated to fluorochromes were used in all studies. The anti-CD45 MoAb, PerCP-conjugate (Becton Dickinson, Cowley, United Kingdom), recognizes the common leukocyte antigen on neutrophils, monocytes, and lymphocytes. MoAbs for the integrin $\alpha$ chain anti-CD11b phycoerythrin conjugate (Dako Ltd, Ely, Cambridge, United Kingdom), anti-CXCR1 phycoerythrin conjugate, and anti-CXCR2 fluorescein isothiocyanate conjugate (both from R \& D Systems, Abingdon, Oxford, United Kingdom) were also used.

\section{Flow Cytometry}

A whole blood method was used to measure chemokine receptor and adhesion molecule expression. ${ }^{8}$ The in vitro response of neutrophils to IL-8 was studied with the use of venous blood from healthy volunteers $(n=4)$. Samples $(100 \mu \mathrm{L})$ of anticoagulated (sodium citrate, $0.105 \mathrm{~mol} / \mathrm{L}$ ) whole blood were incubated with varying concentrations $(0.1-100 \mathrm{nmol} / \mathrm{L}$ ) of IL-8 (PeproTech EC Ltd, London, United Kingdom) at $37^{\circ} \mathrm{C}$ for 30 minutes. Control samples of whole blood were incubated with an equal volume of phosphate-buffered saline solution instead of IL-8. Immunofluorescent flow cytometry was then used to measure CD11b, CXCR1, and CXCR2 surface expression on neutrophils. The patient samples obtained in the CPB study were analyzed with the use of identical immunofluorescent staining methods.

Double-color immunofluorescent staining was analyzed by a bench-top FACScan machine (Becton Dickinson, Cowley, United Kingdom) using LYSYS II software. The 3 major leukocyte subpopulations (neutrophils, lymphocytes, and monocytes) were resolved in real time on the basis of their side light scattering and staining intensity characteristics with the use of anti-CD45 in the FL3 channel. The fluorescent intensity due to bound fluorescein isothiocyanate or phycoerythrin-labeled antibody was monitored 

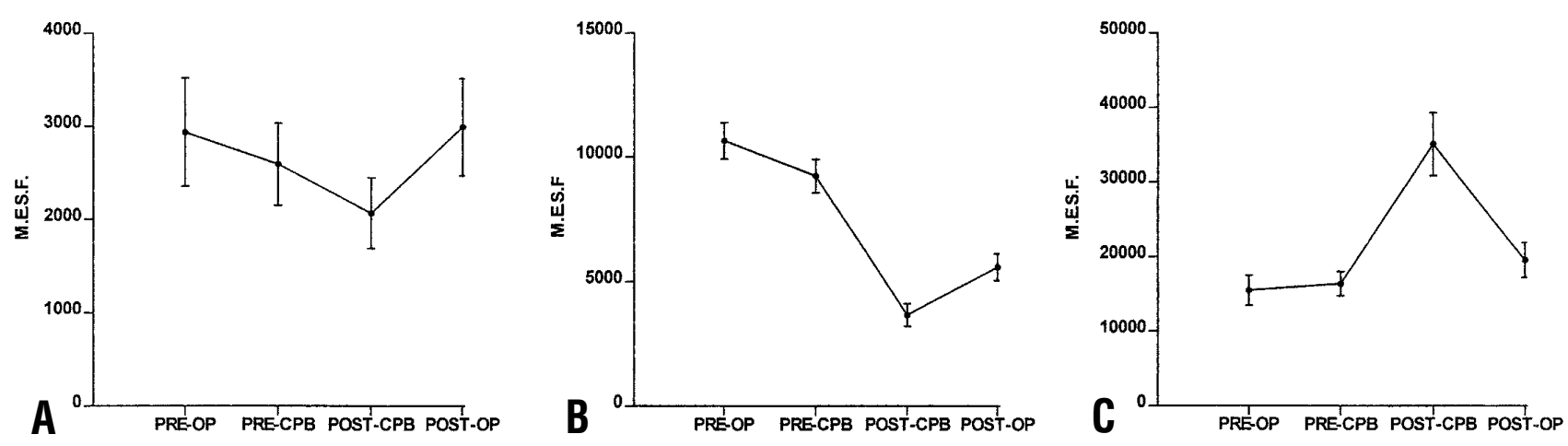

Figure 2. Polymorphonuclear leukocyte CXC receptor and CD11b integrin expression in response to CPB. Each point represents mean $\pm S E M$ of the 10 patients studied and is expressed as molecules of equivalent soluble fluorochromes (M.E.S.F.). A, CXCR1. B, CXCR2. C, CD11b. No significant change in polymorphonuclear leukocyte CXCR1 expression occurred. CXCR2 expression fell significantly after CPB and remained reduced postoperatively $(P<.0001)$. CD11b expression increased significantly $(P<.0001)$ immediately after bypass.

simultaneously in the FL1 and FL2 channels, respectively. Fluorescence was quantified by converting median fluorescent values into molecules of equivalent soluble fluorochrome with the use of calibration fluorescent beads.

\section{Plasma IL-8 Levels}

The plasma IL-8 level was measured by an enzyme-linked immunosorbent assay technique with appropriate positive and negative controls (PharMingen, Becton Dickinson, Cowley, United Kingdom).

\section{Hematology}

Leukocyte and differential white cell counts were analyzed with a cell counter (Coulter STKS Analyzer; Coulter Corporation, Hialeah, Fla).

\section{Statistical Analysis}

The data were analyzed via repeated-measures analysis of variance by the Bonferroni method. Correlations between peak cytokine concentrations or chemokine receptor expression and different parameters were calculated with the Pearson correlation coefficient. Results are expressed as mean \pm standard error of the mean (Arcus Quickstat, Biomedical Version 1.1, Research Solution).

\section{Results}

\section{In Vitro Studies}

Incubation of neutrophils with IL-8 produced a dose-related fall in the expression of both CXCR1 and CXCR2 expression and a rise in CD11b expression (Figure 1). A 10$\mathrm{nmol} / \mathrm{L}$ dose $\left(8 \times 10^{4} \mathrm{pg} / \mathrm{mL}\right)$ of IL- 8 resulted in a decrease of 55\% ( $P=.0004)$ in the expression of CXCR1 (Figure 1, A) compared with control values, and a further fall in expression (90\% of control value) occurred with 100 $\mathrm{nmol} / \mathrm{L}\left(8 \times 10^{5} \mathrm{pg} / \mathrm{mL}\right) \mathrm{IL}-8(P<.0001)$. In contrast, CXCR2 (Figure 1, B) expression was only significantly reduced on incubation with a $100-\mathrm{nmol} / \mathrm{L}\left(8 \times 10^{5} \mathrm{pg} / \mathrm{mL}\right)$ concentration of IL-8 $(P=.003)$. The expression of CD11b
(Figure $1, C)$ increased after exposure to $10 \mathrm{nmol} / \mathrm{L}\left(8 \times 10^{4}\right.$ $\mathrm{pg} / \mathrm{mL})$ IL-8 $(P=.007)$, and a further rise of $400 \%$ compared with control values occurred with $100 \mathrm{nmol} / \mathrm{L}(8 \times$ $\left.10^{5} \mathrm{pg} / \mathrm{mL}\right) \mathrm{IL}-8(P<.0001)$.

\section{Clinical Studies}

The study group comprised 6 men and 4 women with a mean age of $63 \pm 8$ years, all of whom underwent coronary artery bypass grafting. Mean CPB and aortic crossclamp times were $95 \pm 33$ and $53 \pm 24$ minutes, respectively. All subjects made an uneventful recovery and were extubated within 24 hours of surgery. No patient had significant lung injury or organ failure as indicated by low Murray and multiple organ dysfunction scores.

The neutrophil count was significantly elevated immediately after $\mathrm{CPB}\left(12.8 \times 10^{9} / \mathrm{L} ; P<.0001\right)$ and was still raised 12 to 18 hours later $\left(9.0 \times 10^{9} / \mathrm{L} ; P=.0017\right)$ (normal range for the neutrophil counts, $\left.3.5-7.5 \times 10^{9} / \mathrm{L}\right)$. No significant change was observed in the level of expression of CXCR1 after CPB (Figure 2, A). The level of CXCR2 expression (Figure 2, B) fell by an average of $66 \%$ after CPB $(P<.0001)$ and remained significantly depressed compared with preoperative levels 12 to 18 hours later $(P<$ .0001 ). The expression of neutrophil CD11b (Figure 2, $C$ ) increased by an average of $227 \%(P<.0001)$ in the postCPB period. This was followed by a fall in expression to near normal preoperative values by the postoperative stage. IL-8 levels rose significantly to $55.2 \mathrm{pg} / \mathrm{mL}(P<.0001)$ in the immediate post-CPB period. Postoperatively, levels then fell to $26.0 \mathrm{pg} / \mathrm{mL}$ but were still significantly higher than preoperative values $(P=.02)$. No correlation $(P=.5)$ was found between IL-8 plasma levels and CXCR1 receptor expression. A significant correlation $\left(r^{2}=0.39, P<.0001\right)$ was found between IL-8 levels and CXCR2 receptor expression. In addition, a significant correlation $\left(r^{2}=0.71, P=\right.$ 
.03) was found between IL-8 levels and CD11b expression on neutrophils. There was no significant correlation between CXCR1, CXCR2, or CD11b expression and CPB times, ischemic times, alveolar-arterial pressure gradients, or organ dysfunction scores.

\section{Discussion}

We are not aware of previous studies that have investigated the response of CXCR1 and CXCR2 during CPB. We found that neutrophil CXCR2 expression was significantly downregulated after $\mathrm{CPB}$ and remained at a depressed level for at least 12 to 18 hours postoperatively. The reduction in chemokine receptor expression can be explained by internalization of the receptor-ligand complex. This allows destruction of the ligand, receptor recycling, and a continued cellular response to the chemokine. ${ }^{9,10}$ In our study, the interdependence of chemokine receptor and its associated ligand is illustrated by the correlation of changes in CXCR2 expression with plasma IL-8 levels. In comparison, CXCR1 expression remained relatively unchanged throughout the perioperative period, and no correlation with IL-8 levels was found.

Changes in CXC receptor surface expression have important functional consequences for neutrophil chemotaxis. The degree of neutrophil migration across endothelial cell monolayers is proportional to the surface expression of the relevant $\mathrm{CXC}$ receptor. A reduced expression therefore implies a fall in migration, and this has been reported in human sepsis. ${ }^{11}$ Our results suggest that circulating neutrophils are less likely to respond to CXCR2 chemokines after $\mathrm{CPB}$ but will continue to respond to CXCR1 chemokines. This has important implications in the search for antagonists to chemokines and their receptors.

Exposure of neutrophils to increasing concentrations of IL-8 in vitro resulted in a significant down-modulation of both CXC receptors. This differs from our in vivo findings but is in agreement with other in vitro studies. ${ }^{10,12}$ The complex and varied neutrophil-cytokine interactions that occur in vivo during inflammation may explain the differences. In the standard model of neutrophil chemotaxis, neutrophil migration is driven by gradients of soluble chemokines. This model has been modified by Rot and colleagues, ${ }^{13}$ who proposed that the chemokine gradients that mediate leukocyte-endothelial cell adhesion and transmigration are created by chemokines immobilized on the endothelial cell surface. In this model, a dynamic equilibrium would exist in vivo between the circulating pool of IL- 8 and the IL- 8 bound to tissues, endothelium, and red cells. Therefore, the true concentration of IL-8 to which polymorphonuclear leukocyte $\mathrm{CXC}$ receptors are exposed perioperatively would in fact be much higher and not wholly reflected in the concentration of free IL-8 measured in the plasma. This could explain our observations that the concentration of IL-8 required in vivo to down-regulate CXCRs was an order of magnitude higher than the level measured during CPB.

In vivo neutrophils are simultaneously exposed to multiple inflammatory mediators. Tumor necrosis factor $\alpha$, endotoxin, and C5a are elevated after cardiac surgery and can down-regulate neutrophil CXC receptor expression through receptor cross desensitization. ${ }^{14-17}$ Tumor necrosis factor $\alpha$ and C5a result in a sustained loss of CXCR2 expression, whereas CXCR1 expression remains unaffected. ${ }^{15,16}$ Furthermore, after receptor internalization, CXCR1 is reexpressed on the cell surface more rapidly than CXCR2. ${ }^{9} \mathrm{~A}$ number of these mechanisms may explain the differences in $\mathrm{CXC}$ receptor expression after cardiac surgery compared with the situation in vitro.

CD11b is part of the $\beta_{2}$ integrin family of surface adhesion molecules. These molecules mediate firm adhesion of neutrophils to endothelium, which is a prerequisite for subsequent migration into inflamed tissues. ${ }^{18}$ In vitro IL- 8 produced a significant up-regulation in expression of CD11b on exposure to increasing concentrations of IL-8, confirming earlier reports. ${ }^{19}$ Our study demonstrated a temporary elevation in $\mathrm{CD} 11 \mathrm{~b}$ expression after $\mathrm{CPB}$, which rapidly returned to near normal pre-CPB levels by 12 to 18 hours postoperatively. This finding is consistent with previous studies and probably reflects the transient nature of the inflammatory stimulus. ${ }^{20}$

Changes in chemokine receptor expression on neutrophils are likely to be important in the pathogenesis of post-CPB organ damage. We have shown that CXCR2 is down-regulated in patients after CPB, whereas CXCR1 expression remains unchanged. IL-8 is an important determinant of both CXCR1 and CXCR2 expression in vitro but only correlates with CXCR2 expression in the more complex clinical situation.

\section{References}

1. Butler J, Rocker GM, Westaby S. Inflammatory response to cardiopulmonary bypass. Ann Thorac Surg. 1993;55:552-9.

2. Baggiolini M, Dewald B, Moser B. Interleukin-8 and related chemotactic cytokines-CXC and $\mathrm{CC}$ chemokines. Adv Immunol. 1994;55:97-179.

3. Folkesson HG, Matthay MA, Hebert CA, Broaddus VC. Acid aspiration-induced lung injury in rabbits is mediated by interleukin8-dependent mechanisms. J Clin Invest. 1995;96:107-16.

4. Kawamura T, Wakusawa R, Okada K, Inada S. Elevation of cytokines during open heart surgery with cardiopulmonary bypass: participation of interleukin 8 and 6 in reperfusion injury. Can J Anaesth. 1993; 40:1016-21.

5. Jones SA, Dewald B, Clark-Lewis I, Baggiolini M. Chemokine antagonists that discriminate between interleukin- 8 receptors: selective blockers of CXCR2. J Biol Chem. 1997;272:16166-9.

6. Murray JF, Matthay MA, Luce JM, Flick MR An expanded definition of the adult respiratory distress syndrome. Am Rev Respir Dis. 1988;138:720-3.

7. Marshall JC, Cook DJ, Christou NV, Bernard GR, Sprung CL, Sibbald WJ. Multiple organ dysfunction score: a reliable descriptor of a complex clinical outcome. Crit Care Med. 1995;23:1638-52.

8. Macey MG, McCarthy DA, Vordermeier S, Newland AC, Brown KA. Effects of cell purification methods on CD11b and L-selectin expres- 
sion as well as the adherence and activation of leukocytes. J Immunol Methods. 1995;181:211-9.

9. Chuntharapai A, Kim KJ. Regulation of the expression of IL-8 receptor A/B by IL-8: possible functions of each receptor. J Immunol. 1995;155:2587-94.

10. Samanta AK, Oppenheim JJ, Matsushima K. Interleukin 8 (monocytederived neutrophil chemotactic factor) dynamically regulates its own receptor expression on human neutrophils. J Biol Chem. 1990;265:183-9.

11. Cummings CJ, Martin TR, Frevert CW, Quan JM, Wong VA, Mongovin SM, et al. Expression and function of the chemokine receptors CXCR1 and CXCR2 in sepsis. J Immunol. 1999;162:2341-6.

12. Williams MA, Cave CM, Quaid G, Solomkin JS. Chemokine regulation of neutrophil function in surgical inflammation. Arch Surg. 1999;134:1360-6.

13. Rot A, Hub E, Middleton J, Pons F, Rabeck C, Thierer K, et al. Some aspects of IL-8 pathophysiology. III. Chemokine interaction with endothelial cells. J Leukoc Biol. 1996;59:39-44.

14. Riddington DW, Venkatesh B, Boivin CM, Bonser RS, Elliott TS, Marshall T, et al. Intestinal permeability, gastric intramucosal $\mathrm{pH}$, and systemic endotoxemia in patients undergoing cardiopulmonary bypass. JAMA. 1996;275:1007-12.
15. Sabroe I, Williams TJ, Hebert CA, Collins PD. Chemoattractant crossdesensitization of the human neutrophil IL-8 receptor involves receptor internalization and differential receptor subtype regulation. $J$ Immunol. 1997;158:1361-9.

16. Asagoe K, Yamamoto K, Takahashi A, Suzuki K, Maeda A, Nohgawa $\mathrm{M}$, et al. Down-regulation of CXCR2 expression on human polymorphonuclear leukocytes by TNF-alpha. J Immunol. 1998;160:4518-25.

17. Khandaker MH, Xu L, Rahimpour R, Mitchell G, DeVries ME, Pickering JG, et al. CXCR1 and CXCR2 are rapidly down-modulated by bacterial endotoxin through a unique agonist-independent, tyrosine kinase-dependent mechanism. J Immunol. 1998;161:1930-8.

18. Ley K. Molecular mechanisms of leukocyte recruitment in the inflammatory process. Cardiovasc Res. 1996;32:733-42.

19. Detmers PA, Lo SK, Olsen-Egbert E, Walz A, Baggiolini M, Cohn ZA. Neutrophil-activating protein 1/interleukin 8 stimulates the binding activity of the leukocyte adhesion receptor CD11b/CD18 on human neutrophils. J Exp Med. 1990;171:1155-62.

20. Gillinov AM, Bator JM, Zehr KJ, Redmond JM, Burch RM, Ko C, et al. Neutrophil adhesion molecule expression during cardiopulmonary bypass with bubble and membrane oxygenators. Ann Thorac Surg. 1993;56:847-53.

\section{Online-www.aats.org}

Now you can get The Journal of Thoracic and Cardiovascular Surgery online. The Journal online brings you faster delivery time, easy searching of current and back issues, links to PubMed, AATS, WTSA, and other important sites, and more. Visit the Journal online today.

\section{Receive tables of contents by e-mail}

To receive the tables of contents by e-mail, sign up through our Web site at http://www.mosby.com/jtcvs

Choose E-mail Notification

Simply type your e-mail address in the box and click the Subscribe button. Alternatively, you may send an e-mail message to majordomo@mosby.com. Leave the subject line blank and type the following as the body of your message: subscribe jtcvs_toc You will receive an e-mail to confirm that you have been added to the mailing list. Note that TOC e-mails will be sent out when a new issue is posted to the Web site. 